УДК 330.123.3; 336.722.32

DOI https://doi.org/10.32844/2618-1258.2019.3-1.31

НАУМЕНКО С.Г.

\title{
ІСТОРІЯ ТА ПЕРЕДУМОВИ ВИНИКНЕННЯ ФОНДУ ГАРАНТУВАННЯ ВКЛАДІВ ФІЗИЧНИХ ОСІБ В УКРАЇНІ
}

Стаття присвячена основним засадам створення Фонду гарантування вкладів фізичних осіб: історії та передумовам виникнення, завданням, основним функціям і принципам діяльності. Розкрито необхідність введення страхування вкладів в Україні для створення привабливих умов для вкладників. Розглянуто вимоги, необхідні для участі банків у діяльності Фонду гарантування вкладів фізичних осіб. Проаналізовано нормативно-правову базу, що регулює діяльність Фонду гарантування вкладів фізичних осіб. Виокремлено позитивні та негативні сторони Закону України «Про систему гарантування вкладів фізичних осіб». Проаналізовано обсяг фінансових ресурсів Фонду гарантування вкладів фізичних осіб. Наголошено, що непрогнозована гіпервисока інфляція призводить до зменшення доходів і заощаджень бізнесу, населення і держави, підвищення виробничих витрат, збільшення вартості кредитів та їх обслуговування, зростання процентних ставок унаслідок невизначеності щодо майбутнього рівня цін. Окрім вищезазначених наслідків, інфляція створює несприятливі умови для залучення інвестиційних потоків в економіку країни. Інвесторів приваблює лише одноразове, короткотривале інвестування. Дестабілізація в економічному просторі країні зумовлює відсутність економічного зростання. Визначено, що головною функцією держави та Національного банку України є забезпечення стабільності національної валюти - гривні. Одним із способів економічного зростання в Україні є створення привабливого економічного простору для залучення іноземних інвесторів і гарантування стабільності та надійності вкладників. 3'ясовано, що додатковим чинником спокою громадянина, який довірив банку розпоряджатися своїми грошима, є передбачена законодавством гарантія того, що у разі неплатоспроможності банківської установи вкладник отримає компенсацію в розмірі до 200 тис. грн. Саме таким гарантом від імені держави виступає Фонд гарантування вкладів фізичних осіб. Зроблено висновок, що створення такого страхового гандикапу, як Фонд гарантування вкладів фізичних осіб, в Україні набуває позитивних тенденцій, але для повного усунення негативних факторів на фінансову кредитну сферу та посилення довіри громадян до банківської системи України необхідно продовжувати вдосконалювати систему гарантування вкладів.

Ключові слова: Фонд гарантування вкладів фізичних осіб, банківська діяльність, банківська лічензія, система гарантування вкладів фізичних осіб, страхування депозитів, неплатоспроможність банків.

The article is devoted to the foundations of the Deposit Guarantee Fund: the history and background of occurrence, tasks, main functions and principles of activity. The necessity of introducing deposit insurance in Ukraine is revealed to create attractive conditions for depositors. Requirements necessary for the participation of banks in the activity of the Fund for the Guaranteeing of Individual Deposits are considered. The normative-legal framework regulating the activity of the Fund for the Guaranteeing of Individual Deposits is analyzed. The positive and negative aspects of the Law of Ukraine "On the system of guaranteeing deposits of natural persons" are singled out. The volume of financial resources of the Guarantee Fund for Individuals Deposits is analyzed. It is emphasized that the unpredictable hypervisor infrastructure, which

(C) НАУМЕНКО С.Г.--аспірант кафедри фінансового права та фіскального адміністрування (Національна академія внутрішніх справ) 
has to reduce revenues and save the right people, using and refining, most often users, using reliable loans and their services, indicate that rates remain uncertain about specific issues. Some of the overwhelming outlook is that inflation creates unpleasant conditions for increasing current flows in an economic country. Investors are only attracted to one-off, short-term investment investments. Destabilization in the economic space, which causes the presence of the economic level. It determined that the main function and the national Bank of Ukraine is the most modern national currency - the hryvnia. One of the most feasible economic outcomes in Ukraine is to create an attractive economic space for attracting foreign investors and guaranteeing depositors' efficiency and reliability. Given that a current human singer who trusts the bank while keeping his or her money is used, this is a guaranteed legal guarantee of the time that you are insolvent, and this warehouse receives compensation of up to UAH 200,000. The same guarantee on behalf holds this fund, guaranteeing the investment of individuals. A proper analysis has been made that created the same insurance handicap as the Guarantee Fund for the introduction of individuals in Ukraine, who have positive trends, but in order to permanently reduce the negative factors of important credit areas and release trust in the civil system of Ukraine, which requires confirmation of the deposit guarantee system.

Key words: Fund for the Guaranteeing of Individual Deposits, banking, banking license, deposit guaranteeing system, deposit insurance, bank insolvency.

Вступ. 3 давніх часів люди намагаються забезпечити своє майбутнє шляхом накопичення та примноження своїх статків і матеріальних благ, шляхом розміщення вкладів і депозитів у банківські установи. Але ціла низка світових фінансово-економічних криз i, як наслідок, криз в Україні унеможливлює формування зростання доходів громадян (фізичних осіб), а інколи навіть призводить до втрати всіх вкладів i, як наслідок, втрати довіри громадян до фінансово-кредитних інституцій. Саме такі негативні наслідки і спонукали до створення Фонду гарантування вкладів фізичних осіб в Україні.

Аналіз останніх досліджень і публікацій. До питань, що торкаються системи гарантування депозитів в Україні, її правового регулювання у своїх працях зверталось велике коло науковців, переважно економістів. Серед них - А.В. Череп, О.В. Коротава, В.І. Огієнко, Л.Д. Кожухов, Я.О. Берназюк, О.Б. Зайчук, А.Г. Пишний, О.М. Синкова, Т.С. Смовженко та інші. Майже ніколи цю тему не досліджували правники.

Постановка завдання. Метою статті є дослідження передумов створення Фонду гарантування вкладів фізичних осіб, дослідження його правового статусу та обсягу фінансових ресурсів.

Результати дослідження. У поточному році виповнюється 28 років незалежності нашої країни та 23 роки введення в обіг національної валюти - гривні. За період становлення держави та внаслідок декількох хвиль економічного спаду у громадян України неодноразово підривався авторитет до банківської системи та зростала недовіра до фінансово-кредитних інституцій щодо вкладів і депозитів.

Наприклад, після розпаду Радянського Союзу майже кожний українець був позбавлений права вільно розпоряджатися своїми накопиченнями в Ощадбанку СРСР. 3 урахуванням економічної нестабільності та інфляційних процесів у країні депозити почали знецінюватися. У жовтні 1996 року Рада прийняла Закон «Про держгарантії поновлення заощаджень громадян України», що фіксує борг у розмірі 131,96 млрд грн і визначає порядок виплати вкладів Ощадбанку СРСР.

Наступним періодом зневіри громадян до банківських установ стала поява в новій державі Україна власної валюти, що мала б внести позитивні зміни в економіку країни, яка щойно з'явилася на карті Європи. На жаль, поява національної валюти супроводжувалася такими негативними процесами, як інфляція та різкі стрибки цін. Такі явища виникали внаслідок відсутності належного контролю формування цін із боку держави та державних органів.

У період становлення гривні, про яку заговорили ще в 1991 році, та як спосіб відмови від радянського карбованця Україна деякий час користуватися тимчасовою валютою купоно-карбованцями. Саме цей період був визначений для країни наявністю «бідняків-мільйонерів». Саме тимчасовий захід із введенням в обіг українського карбованця або купона мав стати буфером для інфляційного удару. Спочатку планувалося існування такої тимчасової валюти до 6 місяців. Але купони-карбованці проіснували в обігу фактично 5 років. Перші гривні були надруковані в 
Канаді, але в обігу вони так і не з'явилися, а інфляційні процеси в країні набирали гіпертемпів. Наприклад, у 1992-му найвищим номіналом були 100 карбованців, у 1995-му з'явилася купюра 3 шістьма нулями і швидко стала такою ж звичною, як і хліб за 100 чи 200 тисяч. Саме через такі стрибки цін гривню довго не наважувались ввести в обіг [1].

За прогнозами політологів та економістів, нова валюта мала стати не просто папірцем, а сильною валютою. Але прогнозам не судилося збутися, оскільки на заваді гривні стала інфляція. Зокрема, починаючи з 1991 року відсоток інфляції в країні становив 391\%, у 1993 році ця цифра збільшилася у 26 разів і становила $10250 \%$. Зрозуміло, що в такий складний для країни час становлення, в період необхідності збільшення надходжень до бюджету через доходи від капіталу, позитивної тенденції не спостерігалося. В цей період був остаточно підірваний авторитет фінансово-кредитних установ, оскільки дивіденди, нараховані вкладникам за депозити, за лічені місяці перетворювалися на кіпу нічого не вартих папірців.

Зрозуміло, що непрогнозована гіпервисока інфляція призводить до зменшення доходів і заощаджень бізнесу, населення і держави, підвищення виробничих витрат, збільшення вартості кредитів та їх обслуговування, зростання процентних ставок унаслідок невизначеності щодо майбутнього рівня цін. Окрім вищезазначених наслідків, інфляція створює несприятливі умови для залучення інвестиційних потоків в економіку країни. Інвесторів приваблює лише одноразове, короткотривале інвестування. Дестабілізація в економічному просторі країні зумовлює відсутність економічного зростання.

25 серпня 1996 року було прийнято Указ Президента України Леоніда Кучми «Про грошову реформу в Україні», згідно з яким відбувається введення в обіг визначеної чинним законодавством України національної валюти - гривні [2]. Саме відтоді й починається розвиток банківської системи України як складника ринкової інфраструктури та основного елементу ринку депозитних і кредитних ресурсів. У той період стрімко зростає кількість банків, але у зв'язку з недосконалим правовим регулюванням і фінансовими кризами рівень довіри населення до них $€$ низьким, більшість заощаджень зберігалася поза банківськими установами.

Головною функцією держави та Національного банку України є забезпечення стабільності національної валюти - гривні. Одним із способів економічного зростання в Україні $є$ створення привабливого економічного простору для залучення іноземних інвесторів і гарантування стабільності та надійності вкладників.

Тому 10 вересня 1998 року для посилення цієї довіри було прийнято рішення про доцільність створення такої системи гарантування вкладів. Указом Президента України «Про заходи щодо захисту прав фізичних осіб - вкладників комерційних банків» було створено Фонд гарантування вкладів фізичних осіб (далі - Фонд). В той період Україна була однією з перших пострадянських держав, в якій запровадили систему страхування внесків (депозитів). Зокрема, розділом III Указу Президента України «Про заходи щодо захисту прав фізичних осіб - вкладників комерційних банків» джерелами формування коштів Фонду є такі:

- початковий збір із комерційних банків юридичними особами, зареєстрованими в Республіканській книзі реєстрації банків, валютних бірж та інших фінансово-кредитних установ Національного банку України, що мають ліцензію Національного банку України на здійснення операцій із залучення вкладів фізичних осіб;

- регулярні збори з комерційних банків, що сплачують збори до Фонду;

- спеціальні збори з комерційних банків, що сплачують збори до Фонду;

- внесок держави;

- доходи, отримані від інвестування коштів Фонду в державні цінні папери;

- пеня, яка стягується з комерційних банків, що сплачують збори до Фонду, за несвоєчасне або неповне перерахування зборів до Фонду;

- позики комерційних банків, міжнародних фінансових інститутів та іноземних банків;

- інші джерела, не заборонені законодавством України. Внесок держави становить 20 мільйонів гривень і вноситься Національним банком України за кошти його видатків. Збори до Фонду сплачуються комерційними банками - юридичними особами, зареєстрованими в Республіканській книзі реєстрації банків, валютних бірж та інших фінансово-кредитних установ Національного банку України, що мають ліцензію Національного банку України на здійснення операцій із залучення вкладів фізичних осіб.

Сплата зборів зазначеними банками є обов'язковою.

Додатковим чинником спокою громадянина, який довірив банку розпоряджатися своїми грошима, є передбачена законодавством гарантія того, що у разі неплатоспроможності банків- 
ської установи вкладник отримає компенсацію в розмірі до 200 тис. грн. Саме таким гарантом від імені держави виступає Фонд гарантування вкладів фізичних осіб.

Цінова стабільність - це збереження купівельної спроможності національної валюти шляхом підтримання в середньостроковій перспективі (від 3 до 5 років) низьких, стабільних темпів інфляції, що вимірюються індексом споживчих цін. Цінова стабільність не передбачає незмінних цін, вона означає помірне їх зростання.

Фонд гарантування вкладів фізичних осіб заснований із метою захисту прав і законних інтересів вкладників банків.

Наприклад, згідно з розділом II «Правовий статус фонду та його керівні органи» ст. 8 Закону України «Про Фонд гарантування вкладів фізичних осіб» (який зараз втратив чинність):

Фонд є державною спеціалізованою установою, яка виконує функції державного управління у сфері гарантування вкладів фізичних осіб.

Фонд є юридичною особою, має відокремлене майно, яке є об’єктом права державної власності і перебуває у його повному господарському віданні.

Фонд є економічно самостійною установою, яка не має на меті одержання прибутку, має самостійний баланс, поточний та інші рахунки в Національному банку України.

Фонд має печатку із своїм найменуванням, веде облік і звітність відповідно до законодавства.

Фонд розпочав свою діяльність 1998 року з підписанням Президентом України Указу «Про заходи щодо захисту прав фізичних осіб - вкладників комерційних банків». Указом, зокрема, було встановлено, що в разі недоступності вкладу в комерційному банку фізичній особі гарантується відшкодування за вкладом, включно з відсотками, у розмірі вкладу, але не більше 500 гривень.

Основним завданням Фонду є, перш за все, забезпечення функціонування системи гарантування вкладів фізичних осіб, виведення неплатоспроможних банків із ринку.

Фонд $є$ єдиним розпорядником коштів, акумульованих у процесі його діяльності.

Фонд має право придбавати та орендувати майно, необхідне для виконання його функцій, у межах кошторису витрат, затвердженого адміністративною радою і погодженого з Міністерством фінансів України та Національним банком України.

Кошти Фонду не включаються до Державного бюджету України.

Надалі адміністративна рада Фонду збільшувала розмір граничної суми відшкодування коштів за вкладами 11 разів. Сьогодні граничний розмір відшкодування коштів за вкладами - 200000 гривень.

Гарантії Фонду поширюються на фізичних осіб, зокрема фізичних осіб-підприємців.

Усі банки, які мають банківську ліцензію, є учасниками Фонду, окрім АТ «Ощадбанк».

Ще однією ланкою в ланцюгу розвитку системи гарантування вкладів та банківської системи стало прийняття 7 грудня 2000 року Закону України «Про банки і банківську діяльність», який функціонує до сьогодні. Цим законодавчим актом було чітко визначено поняття «банк», «вклад (депозит)» та «кредитор банку», які мають прямий стосунок до функціонування системи гарантування депозитів. Також цим Законом (глава 16) було прописано ліквідацію банків і черговість задоволення вимог кредиторів у разі його неплатоспроможності. 20 вересня 2001 року відбулося прийняття чітко регламентованого Закону України «Про Фонд гарантування вкладів фізичних осіб», який разом із попереднім законом надав поштовх для посилення довіри до банків і бурхливого розвитку вітчизняної банківської системи. Цим Законом встановилися своєрідні засади функціонування Фонду, порядок відшкодування вкладів учасників банків (тимчасових учасників) Фонду у разі відкликання банківської ліцензії та їх ліквідації, а також урегулювалися відносини між Фондом, Кабінетом Міністрів України та Національним банком України. Також новизною цього Закону було зобов'язання банків подавати інформацію про обсяги, порядок відшкодування та види вкладів, що підлягають гарантуванню Фондом. До того ж Фонд гарантування вкладів фізичних осіб отримав право застосування заходів впливу до банку та відкликання банківської ліцензії [3]. Фонд наділявся вузьким колом контрольних функцій і був позбавлений права активно впливати на порушників законодавства. Тобто, на нашу думку, цей Закон значно розширив повноваження Фонду, особливо в частині моніторингу за діяльністю банків. 
Динаміка фінансових ресурсів Фонду за 2001-2019 роки, млрд грн.

\begin{tabular}{|c|c|}
\hline Дата & Фінансові ресурси, млрд грн \\
\hline 01.01 .2001 & 74,3 \\
\hline 01.01 .2005 & 407,0 \\
\hline 01.01 .2010 & 4302,7 \\
\hline 01.01 .2015 & 16872,6 \\
\hline 01.01 .2016 & 14084,4 \\
\hline 01.01 .2017 & 15315,9 \\
\hline 01.01 .2018 & 14354,4 \\
\hline 01.01 .2019 & 14339,2 \\
\hline
\end{tabular}

Проаналізувавши таблицю, ми бачимо, що загальний фінансовий ресурс Фонду гарантування вкладів фізичних осіб з 2001 по 2019 роки збільшився на 174, 3 \%, або на 14,264,9 млрд грн. Як ми можемо побачити, спостерігається масштабне збільшення обсягу фінансових ресурсів Фонду гарантування вкладів фізичних осіб, що свідчить про стабільність фонду.

Станом на 1 квітня 2019 року у реєстрі учасників Фонду гарантування нараховується 77 банків-учасників. Загальна сума коштів, що акумульовані Фондом, станом на 1 квітня 2019 року становить 10 880,374 млн грн. Надходження до Фонду від регулярного збору за січень-березень 2019 року становили 893,04 млн грн.

Загальна сума коштів, отримана вкладниками банків, що були передані в управління Фонду після набрання чинності Закону України «Про систему гарантування вкладів фізичних осіб» від 26 лютого 2012 року, у межах виплати гарантованого відшкодування станом на 1 квітня 2019 року становила 89357,0 млн грн.

Висновки. Отже, аналізуючи викладене, можемо зробити висновок, що створення такого страхового гандикапу, як Фонд гарантування вкладів фізичних осіб, в Україні набуває позитивних тенденцій, але для повного усунення негативних факторів на фінансову кредитну сферу та посилення довіри громадян до банківської системи України необхідно продовжувати вдосконалювати систему гарантування вкладів.

\section{Список використаних джерел:}

1.URL: http://www.fg.gov.ua/231-pres-reliz-fgv/41948-osnovni-pokaznyky-diialnosti-fonduharantuvannia-vkladiv-fizychnykh-osib-stanom-na-pochatok-bereznia-2019-roku.

2.Закон України «Про систему гарантування вкладів фізичних осіб» N 4452-VI від 23 лютого 2012 p.

3.Закон України «Про внесення змін до деяких законів України щодо відшкодування фізичним особам через систему гарантування вкладів фізичних осіб шкоди, завданої зловживаннями у сфері банківських та інших фінансових послуг» № 1736-VIII від 15 листопада 2016 р.

4.Закон України «Про банки і банківську діяльність» від 7 грудня 2000 р. № 2121-III.

5.URL: https://zakon.rada.gov.ua/laws/show/z1548-12.

6.URL: http://journals.uran.ua/index.php/2225-6407/article/view/24194. 